\begin{tabular}{|l|l|l||}
\hline \multicolumn{2}{|c|}{ PublisherInfo } \\
\hline \hline PublisherName & $:$ & BioMed Central \\
\hline \hline PublisherLocation & $:$ & London \\
\hline \hline PublisherImprintName & $:$ & BioMed Central \\
\hline \hline
\end{tabular}

\title{
Hypothermia in acute liver failure
}

\begin{tabular}{|l|l|l||}
\hline \multicolumn{2}{|c||}{ ArticleInfo } \\
\hline \hline ArticleID & $:$ & 4172 \\
\hline \hline ArticleDOI & $:$ & $10.1186 /$ ccf-1999-2322 \\
\hline \hline ArticleCitationID & $:$ & 2322 \\
\hline \hline ArticleSequenceNumber & $:$ & 31 \\
\hline \hline ArticleCategory & $:$ & Paper Report \\
\hline \hline ArticleFirstPage & $:$ & 1 \\
\hline \hline ArticleLastPage & $:$ & 4 \\
\hline \hline & & RegistrationDate : 1999-11-26 \\
ArticleHistory & $:$ & OnlineDate $\quad$ 1999-11-26 \\
\hline \hline ArticleCopyright & $:$ & Current Science Ltd1999 \\
\hline \hline ArticleGrants & $:$ & \\
\hline \hline ArticleContext & $:$ & 1305422 \\
\hline \hline
\end{tabular}




\section{Keywords}

Acute liver failure, ammonia, hypothermia, intracranial hypertension

\section{Comments}

This well conducted pilot study does provide tantalising evidence for the beneficial effects of hypothermia in ALF patients. This contrasts somewhat with the data from neurological centres that have studied this intervention, without demonstrating any significant benefit. I await the outcome of a randomised control trial of this therapy with interest. I also wonder whether hypothermia research will continue to be explored as, for example, a recent comparison of casualties from the Vietnam and Falklands conflicts suggested that moderate hypothermia coupled with a delay in volume resuscitation in the Falklands conflict conferred significant benefit. I suspect that hypothermia may yet develop into a vital intervention in specific circumstances, although its adverse effects, in particular perioperatively, are well documented.

\section{Introduction}

Patients with acute liver failure (ALF) who develop raised intracranial pressure (ICP) and fail to respond to treatment with mannitol and a reduction in circulating volume, have a mortality of $90 \%$ within $12 \mathrm{~h}$. Experiments in animal models of ALF have shown that inducing hypothermia to $32-33^{\circ} \mathrm{C}$ lowers intracranial pressure without adverse effects. In patients with ALF, who fulfil the criteria for orthoptic liver transplantation (OLT), and receive an organ, survival rates of up to $80 \%$ have been achieved. Unfortunately, $30-40 \%$ of such patients die before an organ becomes available, frequently due to uncontrolled intracranial hypertension. All current therapies for treating raised ICP in these patients are, at best, only successful for a very limited time period, with relapses occurring in up to $80 \%$ of patients.

\section{Aims}

To assess the safety and potential efficacy of moderate hypothermia in ALF patients with uncontrolled intracranial hypertension. 


\section{Methods}

All 27 patients admitted to a specialist unit over an 18 month period, who had ALF with grade III-IV encephalopathy, were considered for the trial. Only seven patients were deemed suitable. OLT was performed on four of these patients, the other three did not meet the criteria. Separate protocols were employed for these two groups. The non OLT group were stabilised and then cooled for an $8 \mathrm{~h}$ period, following which they were re-warmed. The OLT group were cooled until an organ became available, and the hypothermia was continued during the operation. A detailed set of haemodynamic and metabolic variables were invasively monitored. Standard statistical analysis was performed on the results.

\section{Results}

All but one of the patients had developed ALF secondary to paracetamol overdose. All patients showed a significant drop in intracranial pressure within $1 \mathrm{~h}$ of cooling. This effect was maintained for the duration of the hypothermia. Other notable effects of cooling were a fall in cardiac index, noradrenaline requirements (to maintain a MAP of $90 \mathrm{~mm} \mathrm{Hg}$ ), cerebral blood flow and cerebral glucose extraction. Cerebral perfusion pressure increased significantly, as did both systemic and cerebral vascular resistance. Arterial and jugular oxygen content and hence cerebral oxygen extraction were unaffected. Perhaps most importantly, there was a cessation of ammonia uptake by cerebral tissue, with arterial levels failing below those in the jugular venous samples.

All of the three non OLT patients died within $12 \mathrm{~h}$ of re-warming. Of the four OLT patients, one suffered a fatal rise in intracranial pressure intraoperatively, the other three survived.

\section{Discussion}

Any treatment that could lengthen the time a patient can survive whilst waiting for OLT could dramatically reduce the mortality from ALF. This extension might only need to be $12-24 \mathrm{~h}$. The authors state that, in their hands, hypothermia was easy to induce, safe and had precisely this effect. The authors hypothesise that this effect is due to the cessation of ammonia uptake by cerebral tissues; ammonia being considered responsible for increasing ICP by inducing water uptake into astrocytes. They are unable, however, to explain the mechanism for this observed phenomenon. They conclude that this pilot study provides sufficient evidence for a randomised control study of moderate hypothermia in ALF patients with raised ICP. 


\section{References}

1. Jalan R, Damink SWMO, Deutz NEP, Lee A, Hayes PC: Moderate hypothermia for uncontrolled intracranial hypertension in acute liver failure. Lancet. 1999, 354: 1164-1168.

This PDF file was created after publication. 